\title{
Precipitation behavior of dispersoids and elevated-temperature properties in Al-Si-Mg foundry alloy with Mo addition
}

\author{
Sinan Chen, Kun Liu*, and X.-Grant Chen \\ Department of Applied Sciences, University of Québec at Chicoutimi \\ 555, boulevard de l'Université, Chicoutimi, QC G7H 2B1, Canada
}

(*Corresponding author: kun.liu @uqac.ca; Tel.: 1-4185455011 ext.7112; Fax: 1-4185455012)

\begin{abstract}
In the present work, Mo was added to an Al-Si-Mg foundry alloy to study its influence on the evolution of dispersoids during various heat treatments. The microhardness as well as the elevatedtemperature tensile properties and creep resistance was measured to evaluate the contribution of dispersoids. Results showed that the addition of Mo greatly promoted the formation of $\alpha$-dispersoids. During solution treatment, the formation of $\alpha$-dispersoids started after 8 hours at $500{ }^{\circ} \mathrm{C}$. At high temperature $\left(540{ }^{\circ} \mathrm{C}\right)$, the coarsening of dispersoids with increasing time became predominant. The optimum condition of dispersoids can be reached by $520^{\circ} \mathrm{C} / 12 \mathrm{~h}$ or $500^{\circ} \mathrm{C} / 4 \mathrm{~h}+540^{\circ} \mathrm{C} / 2 \mathrm{~h}$, leading to the highest differences in microhardness between the Mo-containing alloy and base alloy. The tensile strengths were improved at both room temperature and elevated temperatures, while the elongation at elevated temperature was greatly increased. The creep resistance at elevated temperature is further enhanced due to the Mo addition.
\end{abstract}

Keywords: Al-Si foundry alloy; heat treatment; dispersoids; elevated-temperature properties; creep resistance. 


\section{Introduction}

A significant increase of the usage of aluminum foundry alloys to replace cast iron in aerospace and automotive industries have been witnessed in decades due to their high strength-to-weight ratio, good corrosion resistance and excellent castability [1-3]. One of the examples is the application of Al-Si-Mg foundry alloys in cylinder heads and engine blocks due to the increasing demand from lightweight vehicles $[4,5]$.

Generally, Al-Si-Mg foundry alloys are classified to aging-hardened aluminum alloys through the fine precipitates during the solution and aging treatment. Recent research works have focused on optimizing the properties of $\mathrm{Al}-\mathrm{Si}$ foundry alloys by $\mathrm{Mg}$ and $\mathrm{Cu}$ additions to form $\beta$ '- $\mathrm{Mg}_{2} \mathrm{Si}$ and $\theta^{\prime}-\mathrm{Al}_{2} \mathrm{Cu}$ precipitates [6-9]. It is reported that proper addition of $\mathrm{Cu}(1-1.5 \mathrm{wt} . \%)$ can enhance the mechanical properties of AlSi-Mg alloy by increasing the density of $\beta$ " precipitates [9]. Unfortunately, a severe drop of strength is found when the components are exposed to elevated temperatures, such as $250-350{ }^{\circ} \mathrm{C}$, due to the rapid coarsening of these precipitates [10]. Therefore, attentions have been drawn on the improvement of elevated-temperature properties in $\mathrm{Al}-\mathrm{Si}-\mathrm{Mg}$ foundry alloys, especially on the automobile applications such as cylinder head and engine block components.

One of the practical solutions to improve elevated-temperature properties of aluminum alloys is to introduce a large amount of thermally stable dispersoids via adding rare earth elements or transition elements $[11,12]$. In our previous study on the elevated-temperature behavior of Al-Mn-Mg 3004 alloys $[13,14]$, it is found that the thermally stable $\alpha-\mathrm{Al}(\mathrm{Fe}, \mathrm{Mn}) \mathrm{Si}$ dispersoids can be formed with fine size and 
high volume fraction by adjusting alloying elements, such as $\mathrm{Fe}, \mathrm{Mn}$ and $\mathrm{Cu}$, leading to a remarkable improvement on the strength and creep resistance at $300{ }^{\circ} \mathrm{C}$. Investigations have been performed to study the formation, growth and coarsening behavior of dispersoids at elevated temperature [15-17]. Li et al. [18] reported two possible orientation relationship between $\mathrm{Al}$ matrix and $\alpha-\mathrm{Al}(\mathrm{Fe}, \mathrm{Mn}) \mathrm{Si}$ dispersoids and studied the thermal stability of the dispersoids. Lodgaard et al. [19] studied the effect of the heating procedure on dispersoid distribution and concluded that the slow heating rate could result in uniform and high density of dispersoids. Crystal structure and morphology of dispersoids are determined by Kim et al. [20]. Li et al. [21] also studied quantitatively on the precipitation behavior of Mn-containing dispersoids during heating and homogenization processes. Moreover, the effects of dispersoids on tensile properties $[22,23]$ and fatigue properties $[24,25]$ of $\mathrm{Al}-\mathrm{Zn}-\mathrm{Mg}$ alloy have been studied. Improvements were witnessed on mechanical properties due to the presence of $\alpha-\mathrm{Al}(\mathrm{Fe}, \mathrm{Mn}) \mathrm{Si}$ dispersoids.

However, limited literature can be found on the effect of dispersoids in Al-Si-Mg foundry alloys. Farkoosh et al. $[26,27]$ reported that Mo, combining with Mn, had great potential to form a large amount of dispersoids in $\mathrm{Al}-\mathrm{Si}-\mathrm{Mg}$ alloys and could improve elevated-temperature properties. However, the precipitation behavior of dispersoids during heat treatment was unclear. In the present work, the precipitation behavior of dispersoids in Al-Si-Mg 356-type alloys during heat treatments with various temperatures and soaking times was systematically studied. The evolution of dispersoids during heat treatment was characterized with their size and number density and was further confirmed by the microhardness changes. Furthermore, the role of Mo-containing dispersoids on tensile properties at room and elevated temperatures as well as the creep resistance at $300{ }^{\circ} \mathrm{C}$ was also evaluated. 


\section{Results and discussion}

\subsection{Microstructure in as-cast and solution-treated conditions}

Fig. 1 shows the as-cast microstructures of experimental 356NM and 356M alloys. As can be seen, the microstructures of both alloys are similar, which is consisted of $\alpha$-Al dendrites, refined eutectic Si particles as well as various intermetallic phases located in the interdendrite regions. The secondary dendrite arm spacing (SDAS) was measured to be $30 \pm 8 \mu \mathrm{m}$ for $356 \mathrm{NM}$ alloy and $31 \pm 8 \mu \mathrm{m}$ for $356 \mathrm{M}$ alloy, respectively. Fig. $1 \mathrm{~b}$ and $1 \mathrm{~d}$ shows the detailed information of various intermetallics. Two kinds of Fe-containing phases $\left(\alpha-\mathrm{Al}(\mathrm{Fe}, \mathrm{Mn}) \mathrm{Si}\right.$ and $\left.\pi-\mathrm{Al}_{8} \mathrm{FeMg}_{3} \mathrm{Si}_{6}\right)$, two $\mathrm{Cu}$-containing phases $\left(\mathrm{Q}-\mathrm{Al}_{5} \mathrm{Cu}_{2} \mathrm{Mg}_{8} \mathrm{Si}_{6}\right.$ and $\theta-\mathrm{Al}_{2} \mathrm{Cu}$ ) and $\mathrm{Mg}_{2} \mathrm{Si}$ are all found in both alloys, while a small amount of Mo is detected in $\alpha-$ $\mathrm{Al}(\mathrm{Fe}, \mathrm{Mn}) \mathrm{Si}$ intermetallics in 356M alloy (Fig. 1d). One thing to be mentioned that no platelet/needlelike $\beta-\mathrm{Al}_{5} \mathrm{FeSi}$ phase was observed in both $356 \mathrm{NM}$ and $356 \mathrm{M}$ alloys. This can be attributed to a relatively high amount of $\mathrm{Mn}$ in 356NM and 356M alloys, which was reported to effectively promote the transformation from $\beta-\mathrm{Al}_{5} \mathrm{FeSi}$ to $\alpha-\mathrm{Al}(\mathrm{Fe}, \mathrm{Mn}) \mathrm{Si}[28,29]$. In addition, Mo was also reported to modify the $\beta$-Fe to $\alpha-\mathrm{Fe}$ in Al-Si 356 alloys $[26,30]$. Hence, it is reasonable to expect the $\alpha-\mathrm{Al}(\mathrm{Fe}, \mathrm{Mn}) \mathrm{Si}$ rather than $\beta-\mathrm{Al}_{5} \mathrm{FeSi}$ in two experimental alloys.

During solution treatment, the eutectic Si particles were spheroidized while primary $\mathrm{Mg}_{2} \mathrm{Si}, \mathrm{Q}-$ $\mathrm{Al}_{5} \mathrm{Cu}_{2} \mathrm{Mg}_{8} \mathrm{Si}_{6}$ and $\theta-\mathrm{Al}_{2} \mathrm{Cu}$ intermetallics presented in the as-cast microstructure were gradually dissolved in the aluminum matrix with increasing temperature and soaking time for both alloys. The microstructure of both alloys after solution-treated at $540{ }^{\circ} \mathrm{C}$ for $8 \mathrm{~h}$ is shown in Fig. 2 as one example. As can be seen 
that the eutectic Si particles are much smaller and spheroidized compared to that in as-cast condition. On the other hand, fine dispersoids were formed and distributed in the intradendritic region of 356NM and 356M alloys. It can be seen that only a few of dispersoids appeared in the matrix of 356NM alloy (Fig. 2a), while a large number of dispersoids formed in the matrix in 356M alloy (Fig. 2b), which were centered inside aluminum cells. The number density of dispersoids is much higher in 356M than 356NM alloy, indicating that the addition of Mo greatly promotes the formation of dispersoids. Meanwhile, the dispersoid free zone (DFZ) can be observed between two adjacent dispersoid zones. The segregation of Mo in the centers of aluminum dendrites due to its partition coefficient larger than unity $\left(\mathrm{k}_{\mathrm{Mo}}=2.5\right.$ [31]) results in the origin of DFZ. Meanwhile, the coarsening between the fine dispersoids and coarse constituent particles/intermetallics during the solution treatment can also result in the formation of DFZ $[21,32]$.

TEM observation was performed on those fine dispersoids in Fig. 2. They were all identified as $\alpha$ $\mathrm{Al}(\mathrm{Fe}, \mathrm{Mn} / \mathrm{Mo}) \mathrm{Si}$ dispersoids and hence " $\alpha$-dispersoids" is used in the following text. The TEM analysis in 356M alloy is shown in Fig. 3 as an example. The diameter of $\alpha$-dispersoids is approximately $100 \mathrm{~nm}$ (Fig. 3a) and the semi-coherent boundary between $\alpha$-dispersoids and Al matrix can be observed in Fig. $3 b$. Fig. $3 \mathrm{c}$ and $3 \mathrm{~d}$ shows the TEM-EDS results of $\alpha$-dispersoids and surrounding matrix in $356 \mathrm{M}$ alloy. It can be found the content of $\mathrm{Si}, \mathrm{Mn}$ and $\mathrm{Mo}$ in $\alpha$-dispersoids is much higher than the matrix, which is $2.16 \%$ $0.43 \%$ and $1.45 \%$ in $\alpha$-dispersoids compared with $1.7 \%, 0.1 \%$ and $0.24 \%$ in matrix, respectively, further confirming the composition of $\alpha$-dispersoids with Mn and Mo. 


\subsection{Evolution of $\alpha$-dispersoids during solution treatment}

As shown in Fig. 2, a large number of $\alpha$-dispersoids in 356M alloy but a few of big ones in 356 NM can be observed after $540^{\circ} \mathrm{C} / 8 \mathrm{~h}$, indicating the different formation behaviors of dispersoids in two alloys. Therefore, the solution treatment under various conditions (see Section 4 - Experimental procedure) was applied to study the effect of temperature and soaking time on the evolution of dispersoids. The general tendency of the dispersoid evolution with increasing solution temperature for $24 \mathrm{~h}$ is presented in Fig. 4. It can be observed that the number density of $\alpha$-dispersoids increased when the temperature increases from $500{ }^{\circ} \mathrm{C}$ (Fig. 4a) to $520{ }^{\circ} \mathrm{C}$ (Fig. 4b), and however, the number density of $\alpha$-dispersoids moderately decreased when the temperature further increases to $540{ }^{\circ} \mathrm{C}$ (Fig. 4c).

The Vickers microhardness measurements were carried out on both experimental alloys right after the solution heat treatment. In order to clearly show the general tendency and the differences between two alloys, the evolution of hardness with temperature in 356NM and the differences of Vickers microhardness $(\Delta \mathrm{HV})$ of $356 \mathrm{NM}$ and $356 \mathrm{M}$ during the solution treatment at various temperatures are shown in Fig. 5. As shown in Fig. 5a, the microhardness of 356NM keeps almost unchanged at $500{ }^{\circ} \mathrm{C}$ and starts to increase at higher temperatures $\left(520^{\circ} \mathrm{C}\right.$ and $\left.540^{\circ} \mathrm{C}\right)$ with increasing holding time, principally due to the dissolution of primary $\mathrm{Mg}_{2} \mathrm{Si}$ and $\mathrm{Al}_{2} \mathrm{Cu}$. On the other hand, it can be found the $\Delta \mathrm{HV}$ is always positive in Fig. $5 \mathrm{~b}$, indicating the higher hardness in $356 \mathrm{M}$ than that in $356 \mathrm{NM}$. Due to the fact that $\Delta \mathrm{HV}$ is greatly related to the condition of the aluminum matrix, especially to the decomposition of supersaturated solid solution to form dispersoids, the tendency of $\Delta \mathrm{HV}$ can be considered as a clear indicator for the evolution of $\alpha$ - 
dispersoids in 356M alloy. As shown in Fig. 5b, different tendencies can be observed under various temperatures. When treated at $500{ }^{\circ} \mathrm{C}, \Delta \mathrm{HV}$ is very low in the first $4 \mathrm{~h}$ and then slowly increases with increasing soaking time. After $8 \mathrm{~h}$, it reaches a plateau. At $520^{\circ} \mathrm{C}, \Delta \mathrm{HV}$ rapidly increases to the peak value after $12 \mathrm{~h}$ followed by a plateau. At this temperature, the highest $\Delta \mathrm{HV}$ of $\sim 20 \mathrm{HV}$ is obtained, which is $25 \%$ improvement compared with that in $356 \mathrm{NM}$ ( $83 \mathrm{HV}$ max. at $520{ }^{\circ} \mathrm{C}$ in Fig. 5a). With further increasing solution temperature to $540{ }^{\circ} \mathrm{C}, \Delta \mathrm{HV}$ rapidly increases to the peak value after $4 \mathrm{~h}$, after that it starts to decrease with increasing holding time. As for the two-step solution treatment, the highest $\Delta \mathrm{HV}$ appears at $2 \mathrm{~h}$ at $540{ }^{\circ} \mathrm{C}$ and the peak value reaches the same level as that of $520^{\circ} \mathrm{C} / 12 \mathrm{~h}$. Followed by the peak, there is a gradual drop of $\Delta \mathrm{HV}$. Since the formation of dispersoids is very weak in the base alloy (356NM) in all solution treatment conditions applied, as shown in Fig. 2a, and therefore, only the evolution of dispersoids in 356M alloy is discussed in details in the following section.

Fig. 6 shows the evolution of the number density and average equivalent diameter of $\alpha$-dispersoids during solution treatment at different temperatures, analyzed by image analysis on a series of SEM images as shown exemplary in Fig. 7. As shown in Fig. 6 a, when treated at $500{ }^{\circ} \mathrm{C}$, the formation of dispersoids is hardly observed until $8 \mathrm{~h}$. After 8 hours the dispersoids are visible under SEM and the number density of dispersoids increases slowly with increasing soaking time. The average size of dispersoids is approximately $100 \mathrm{~nm}$. It is apparent that the formation of dispersoids after $8 \mathrm{~h}$ results in an increase of $\Delta \mathrm{HV}$ in Fig. 5. After 24 hours, the number density and average size of dispersoids still keep at a low level. Therefore, the increase of $\Delta \mathrm{HV}$ is limited $(5-8 \mathrm{HV})$ at $500{ }^{\circ} \mathrm{C}$. It can be concluded that the kinetic of the dispersoid formation is quite slow at such temperature and it needs a long incubation time to form Mo- 
containing $\alpha$-dispersoids, most likely attributing to a low diffusion coefficient of Mo in aluminum at $500{ }^{\circ} \mathrm{C}\left(1.8 \times 10^{-20} \mathrm{~m}^{2} \mathrm{~s}^{-1}[33]\right)$.

With increasing solution temperature to $520^{\circ} \mathrm{C}$ (Fig. 6b), a number of dispersoids can be clearly observed during first 2-4 h soaking. After 4 hours, the number density of dispersoids increases rapidly with increasing soaking time, indicating a full precipitation of dispersoids. During solution treatment, the average dispersoid size increases gradually from $120 \mathrm{~nm}$ (after $2 \mathrm{~h}$ ) to $150 \mathrm{~nm}$ (after $24 \mathrm{~h}$ ). It is evident that the kinetic of the dispersoid formation here is more favorable than at $500^{\circ} \mathrm{C}$, because that the diffusion coefficient of Mo in aluminum at $520^{\circ} \mathrm{C}\left(1.9 \times 10^{-19} \mathrm{~m}^{2} \mathrm{~s}^{-1}[33]\right)$ is ten times higher than $500{ }^{\circ} \mathrm{C}\left(1.8 \times 10^{-20}\right.$ $\left.\mathrm{m}^{2} \mathrm{~s}^{-1}\right)$. The evolution of dispersoids in Fig. $6 \mathrm{~b}$ also well explains the tendency of $\Delta \mathrm{HV}$ at $520{ }^{\circ} \mathrm{C}$ shown in Fig. 5. The formation of dispersoids with increasing number density leads to the increasing $\Delta H V$ until to the peak value at 12 hours. As shown in Fig. 6b, the number density of dispersoids is much higher after $520^{\circ} \mathrm{C} / 12 \mathrm{~h}$ compared with that after $500^{\circ} \mathrm{C} / 24 \mathrm{~h}$. Therefore, the peak value of $\Delta \mathrm{HV}$ at $520^{\circ} \mathrm{C} / 12 \mathrm{~h}$ is much higher than $500^{\circ} \mathrm{C} / 24 \mathrm{~h}(20 \mathrm{HV}$ vs $7 \mathrm{HV})$, confirming a remarkable contribution of $\alpha$-dispersoids on the strength. After that, the plateau on the $\Delta \mathrm{HV}$ is attributed to the balance between the increasing number density and coarsening of dispersoids.

The evolution of $\alpha$-dispersoids at $540{ }^{\circ} \mathrm{C}$ is shown in Fig. 6c. The number density of dispersoids increases gradually during the first $8 \mathrm{~h}$ soaking, which contributes to the rapid increasing of $\Delta \mathrm{HV}$ in Fig. 5. After 8 hours, the coarsening of dispersoids becomes the main mechanism, which leads to a quick drop of number density and a sustainable increase of particle size. The decline of $\Delta \mathrm{HV}$ after $8 \mathrm{~h}$ also reflects the time point when coarsening becomes obvious. With increasing temperature to $540{ }^{\circ} \mathrm{C}$, the diffusion 
coefficient of Mo is significantly enhanced to be $4.6 \times 10^{-19} \mathrm{~m}^{2} \mathrm{~s}^{-1}$, which makes Ostwald ripening possible between dispersoids, resulting in a decrease of the number density and an increase of the dispersoid size.

Fig. 6d illustrates the evolution of dispersoids during two-step solution treatment. During the first 2 hours soaking, the highest number density of dispersoids is already observed relative to other three solution treatments at the same soaking time. It indicates that the first step of treatment $\left(500^{\circ} \mathrm{C} / 4 \mathrm{~h}\right)$ provides a good incubation time for the nucleation of dispersoids. During the second step of treatment at $540{ }^{\circ} \mathrm{C}$, the dispersoids can quickly grow out in the matrix in a short period of the time. With increasing soaking time at the second step, the number density of dispersoids remains more and less constant, while the average dispersoid size increases gradually. The maximum $\Delta \mathrm{HV}$ value appears after $2 \mathrm{~h}$ when the dispersoid diameter is the smallest during soaking (Fig, 6). After that, the continuous increase of the dispersoid size causes a gradual decrease of $\Delta \mathrm{HV}$.

As can be seen in Fig. 5, the maximum $\Delta \mathrm{HV}$ value is obtained at $520^{\circ} \mathrm{C} / 12 \mathrm{~h}$ and $500^{\circ} \mathrm{C} / 4 \mathrm{~h}+540^{\circ} \mathrm{C} / 2 \mathrm{~h}$. Therefore, the dispersoid evolutions during $520^{\circ} \mathrm{C}$ (one step) and $500^{\circ} \mathrm{C} / 4 \mathrm{~h}+540^{\circ} \mathrm{C}$ (2 steps) treatments are illustrated in details (Fig. 7). When soaking at $520^{\circ} \mathrm{C}$, it takes less than 2 hours for dispersoids to precipitate in the matrix (Fig. 7a), which is much faster than at $500{ }^{\circ} \mathrm{C} \mathrm{(Fig.} \mathrm{6a} \mathrm{and} \mathrm{b).} \mathrm{After} 12$ hours, fine dispersoids with high number density are present (Fig. 7b). With increasing holding time to 24 hours (Fig. 7c), the size of dispersoid and number density keep increasing, indicating a full precipitation of dispersoids at this temperature. The two-step solution treatment is often preferably used in industrial production because of (i) avoiding possible incipient melting of Cu-containing phases and (ii) a short and effective solution treatment. As shown in Fig. $7 \mathrm{~d}$ after $500^{\circ} \mathrm{C} / 4 \mathrm{~h}+540^{\circ} \mathrm{C} / 2 \mathrm{~h}$, the dispersoids are already precipitated 
with high number density but still with fine size. However, with increasing holding time of the second step, the size of $\alpha$-dispersoids increases, as shown in Fig. $7 \mathrm{e}$ and $7 \mathrm{f}$, leading to a decrease of $\Delta \mathrm{HV}$ after the peak value at 2 hours (Fig. 5).

\subsection{Tensile properties}

For the role of $\alpha$-dispersoids in mechanical properties, both experimental alloys were subjected the optimum two-step solution treatment $\left(500^{\circ} \mathrm{C} / 4 \mathrm{~h}+540^{\circ} \mathrm{C} / 2 \mathrm{~h}\right)$ followed by an artificial aging at $200{ }^{\circ} \mathrm{C}$ for 5 hours to fulfil the T7 temper. Typical stress-strain curves obtained for 356NM and 356M alloys at room temperature and $300{ }^{\circ} \mathrm{C}$ are shown in Fig. 8. At room temperature (Fig. 8a), the values of YS and UTS obtained in both experimental alloys are comparable to commercial Al-Si $356+\mathrm{Cu}$ alloys with the YS of 270-280 MPa and UTS of 300-320MPa, which are mainly strengthened by the precipitation of nano-scale $\beta^{\prime}-\mathrm{Mg}_{2} \mathrm{Si}$ and $\theta^{\prime}-\mathrm{Al}_{2} \mathrm{Cu}$ precipitates. On the other hand, compared to the base alloy (356NM), YS and UTS of 356M are found to be $8.7 \mathrm{MPa}$ and 13.6 MPa higher respectively without sacrificing ductility. Since the addition of Mo has little influence on the formation of precipitates ( $\beta^{\prime}$ and $\left.\theta^{\prime}\right)$ during the aging treatment, it is reasonable to assume that the contribution of precipitates on the mechanical properties in both alloys is similar. Therefore, the improvement on the mechanical properties at room temperature in $356 \mathrm{M}$ alloy is principally from the formation of dispersoids, indicating a complementary strengthening contribution of $\alpha$-dispersoids on alloy mechanical properties at room temperature. In 356M alloy, the presence of the $\alpha$-dispersoids can act as non-shearable obstacles to impede dislocation movement in the aluminum matrix, which are effective in Orowan bypass mechanism $[26,30]$ providing a small but extra 
strengthening. Meanwhile, the difference of microhardness between $356 \mathrm{M}$ and $356 \mathrm{NM}$ in $\mathrm{T} 7$ temper is measured to be $13 \mathrm{HV}(112 \mathrm{HV}$ vs. $99 \mathrm{HV})$, which is similar to the difference at as solution treated condition (15 HV), indicating the stable contribution of dispersoids in both conditions.

At elevated temperature $\left(300{ }^{\circ} \mathrm{C}\right)$, the YS and UTS of $356 \mathrm{M}$ alloy is 4 and $5 \mathrm{MPa}$ higher than $356 \mathrm{NM}$ alloy, mainly attributed to the formation of dispersoids in $356 \mathrm{M}$ alloy since the contribution on the elevated-temperature mechanical properties from precipitates ( $\beta^{\prime}$ and $\left.\theta^{\prime}\right)$ should be similar in both alloys. Though the improvement is not so remarkable $(\sim 5 \%)$ at this condition, it is expected to be more obvious during the long time service at $300{ }^{\circ} \mathrm{C}$ because the contribution of dispersoids is constant (4-5MPa) due to their excellent thermal stability at $300-350{ }^{\circ} \mathrm{C}$ [13]. It is reported the $\mathrm{YS}$ of $356-\mathrm{T} 7$ at $315^{\circ} \mathrm{C}$ after 1000 hours sharply decreases and remains only $24 \mathrm{MPa}$ [34]. At long time service condition, the contribution of thermally stable dispersoids on YS will become remarkable, which would reach as high as $20 \%$ improvement on strength (4-5 MPa compared with $24 \mathrm{MPa}$ ) with $0.3 \%$ Mo addition in $356 \mathrm{M}$ alloy.

On the other hand, the elongation at $300{ }^{\circ} \mathrm{C}$ increases significantly from $7.5 \%$ (356NM) to $13.9 \%$ (356M) in Fig. 8b. This can be also resulted from the dislocation-dispersoid interaction during the deformation. In the early stage of the tensile deformation, the dislocation density is low due to the elevated temperature [35], leading to the similar tensile behavior during elastic deformation at the beginning of test, as shown in Fig. 8b. As the plastic deformation proceeds, dislocation density rises [36] and the effect of dislocation-dispersoid/precipitation interactions become more remarkable.

Sitdikov et al. [37] noted a strong dislocation-dispersoid interaction during high temperature deformation and suggested that the dispersoids could trap the dislocations significantly. Furthermore, it is reported that the 
present of dispersoids will change the slip system by means of cross-slip once the dislocation is blocked by dispersoids, making the homogenization of slip and then increasing the ductility [22-24]. On the other hand, it is also found that the homogeneous deformation is greatly promoted by converting the dislocation movement from the planar slip to a wavy slip mode through cross slip [24,25], which also contributes to the improvement on the ductility. Therefore, it is reasonable to believe that the higher elongation in $356 \mathrm{M}$ than $356 \mathrm{NM}$ in present work can be likely also attributed to the formation of $\alpha$-dispersoids.

The fracture surfaces after tensile tests at both room and elevated temperatures are shown in Fig. 9. As shown in Fig. 9a and 9b at room temperature, the fractures in both 356NM and 356M alloys exhibit typical mixed cellular fracture, reflecting the similar tensile behavior of both alloys at room temperature. Fig. $9 \mathrm{c}$ and $9 \mathrm{~d}$ shows the fracture surfaces of the tested samples at $300{ }^{\circ} \mathrm{C}$. High volume of dimples can be observed in both experimental alloys (Fig. $9 \mathrm{c}$-d), exhibiting the ductile tensile behavior. The formation of dimples is the result of the void nucleation and subsequent coalescence during tensile deformation [38, 39]. Compared Fig. 9d to Fig. 9c, a finer and more uniform dimple size distribution is observed in the $356 \mathrm{M}$ than 356NM alloy, which can be attributed to a homogenous deformation due to the presence of dispersoids, leading to the higher elongation in $356 \mathrm{M}$ alloy. Furthermore, more energy needs to be consumed during the final fracture due to the high density of particle-matrix interfaces, thus results in better tensile toughness of $356 \mathrm{M}$ alloy [40].

As one of the most important properties at elevated temperature, the creep properties of experimental alloys at T7 condition was also measured in the present work. The typical creep curves are shown in Fig. 10 obtained from compressive creep tests after 100 hours. One thing to be mentioned is that the strain of 
0.25 is the limit of the creep machine. As shown in Fig. 10, it takes 80 hours to reach the strain of 0.25 in $356 \mathrm{NM}$ alloy, which is the maximum strain of the creep machine at compression mode, while strain reaches only 0.19 even after 100 hours in $356 \mathrm{M}$ alloy. Besides, the minimum creep rates are calculated to be $1.3 \times 10^{-6} \mathrm{~s}^{-1}$ for $356 \mathrm{NM}$ alloy and $7.7 \times 10^{-7} \mathrm{~s}^{-1}$ for $356 \mathrm{M}$ alloy, respectively, representing $40 \%$ reduction of the minimum creep rate in the Mo-containing 356M alloy. In addition, the quasi-steady stage is also indicated in Fig. 10, which is the most important stage during the creep test, especially the compression creep test [41]. It can be found that the time during the quasi-steady stage is only $30 \mathrm{~h}$ in $356 \mathrm{NM}$ but it is $58 \mathrm{~h}$ for $356 \mathrm{M}$, which is almost doubled in the alloy containing Mo. Therefore, it is also confirmed that the alloy 356M has much higher creep resistance than 356NM.

According to the creep condition applied in the present work $\left(43.5 \mathrm{MPa}\right.$ at $\left.300{ }^{\circ} \mathrm{C}\right)$, the creep mechanism is primarily controlled by the climb and glide of dislocations during creep deformation [41]. Therefore, the creep resistance can be affected by the factors that can interact with the movement of dislocations, including precipitates formed during aging treatment and dispersoids formed during the solution treatment. As mentioned above, both alloys in $\mathrm{T} 7$ condition are mainly strengthened by similar distribution of nano-scale $\beta^{\prime}-\mathrm{Mg}_{2} \mathrm{Si}$ and $\theta^{\prime}-\mathrm{Al}_{2} \mathrm{Cu}$ precipitates. However, those precipitates were rapidly coarsening at elevated temperature $\left(300^{\circ} \mathrm{C}\right)$, causing the decreasing strength of alloys with time. The difference between $356 \mathrm{NM}$ and $356 \mathrm{M}$ is the presence of a high number density of thermally stable dispersoids in $356 \mathrm{M}$ alloy, which can effectively hinder the movement of dislocations, resulting in a remarkable improvement of the creep resistance in 356M alloy.

As shown in Figs. 8 and 10, the formation of $\alpha$-dispersoids due to the Mo addition provides an 
additional contribution to mechanical properties at both room and elevated temperatures. It is well proven that the $\alpha$-dispersoids are thermally stable at $300-350{ }^{\circ} \mathrm{C}[31]$, and therefore, the mechanical and creep properties of components made with Mo-containing 356 alloys can be less deteriorated during long time service at elevated temperature compared to conventional 356 alloys, providing a longer service life. On the other hand, it should be mentioned that the improvement of mechanical properties by the formation of $\alpha$-dispersoids in the present experiment condition is marginal, although a reasonably high number of $\alpha$ dispersoids were promoted by the addition of Mo and suitable heat treatment. In term of strengthening mechanisms, the size of $\alpha$-dispersoids precipitated (in the range of $100-150 \mathrm{~nm}$ ) is still large and the number density is not high enough. To take the full advantage of thermally stable dispersoids on further increasing the mechanical properties particularly at elevated temperature, it remains a great challenge to refine dispersoids and to increase the volume fraction of dispersoids in the future work.

\section{Conclusions}

1) With the addition of Mo in Al-Si-Mg 356-type alloy, the formation of $\alpha$-dispersoids in the aluminum matrix during solution treatment was greatly promoted. A reasonably high number density of $\alpha$-dispersoids were formed and distributed in the intradendritic region.

2) The solution temperature had a strong effect on the precipitation kinetic of dispersoids in the Mocontaining 356 alloy. The formation of dispersoids started after 8 hours at $500{ }^{\circ} \mathrm{C}$ and a full precipitation with increasing time occurred at $520^{\circ} \mathrm{C}$. At high temperature $\left(540{ }^{\circ} \mathrm{C}\right)$, the coarsening of dispersoids with increasing time became predominant. The optimum conditions of dispersoids can be reached by 
$520^{\circ} \mathrm{C} / 12 \mathrm{~h}$ or $500^{\circ} \mathrm{C} / 4 \mathrm{~h}+540^{\circ} \mathrm{C} / 2 \mathrm{~h}$, leading to the highest differences in the microhardness.

3) Due to a complementary strengthening contribution of $\alpha$-dispersoids, the tensile strengths were improved at both room temperature and elevated temperatures. The elongation was keeping similar at room temperature, while it was greatly improved at elevated temperature.

4) The formation of thermally stable dispersoids due to the Mo addition also resulted in a remarkable improvement of the creep resistance with $40 \%$ reduction of the minimum creep rate.

\section{Experimental procedures}

In the present work, two experimental Al-Si-Mg 356-type alloys, defined as 356NM (the base alloy without $\mathrm{Mo}$ ) and 356M with Mo addition, are prepared with commercially pure $\mathrm{Al}$ (99.7\%), pure $\mathrm{Mg}$ (99.9\%), Al-50\%Si, Al-25\%Mn, Al-50\%Cu, Al-10\%Sr and $\mathrm{Al}-5 \% \mathrm{Ti}-1 \% \mathrm{~B}$ master alloys. The chemical composition of $356 \mathrm{NM}$ is $\mathrm{Al}-7.27 \% \mathrm{Si}-0.60 \% \mathrm{Cu}-0.34 \% \mathrm{Mg}-0.206 \mathrm{Mn} \%-0.109 \% \mathrm{Fe}-0.21 \% \mathrm{Ti}-0.0113 \% \mathrm{Sr}$ while it is $\mathrm{Al}-6.99 \% \mathrm{Si}-0.61 \% \mathrm{Cu}-0.38 \% \mathrm{Mg}-0.219 \mathrm{Mn} \%-0.11 \% \mathrm{Fe}-0.21 \% \mathrm{Ti}-0.0113 \% \mathrm{Sr}-0.30 \% \mathrm{Mo}$ for 356M (all the composition is in wt.\% unless indicated otherwise).

For the casting process, pure $\mathrm{Al}$ and master alloys were melt and stirred to homogenize in claygraphite crucible at $780{ }^{\circ} \mathrm{C}$ in an electric resistance furnace with protective atmosphere. The temperature

of the melt was maintained at $780{ }^{\circ} \mathrm{C}$ for $30 \mathrm{~min}$ and then was degassed for $15 \mathrm{~min}$. Finally, the liquid alloys were cast into a standard ASTM B-108 permanent mold pre-heated at $400{ }^{\circ} \mathrm{C}$.

To evaluate the precipitation behavior of dispersoids, isothermal solution treatment was firstly applied in the temperature range of $500-540^{\circ} \mathrm{C}$ with a heating rate of $5{ }^{\circ} \mathrm{C} / \mathrm{min}$ and with various soaking times up 
to $24 \mathrm{~h}$. In addition, the two-step solution treatment (soaking $4 \mathrm{~h}$ at $500{ }^{\circ} \mathrm{C}$ followed by $2,4,8$ and $12 \mathrm{~h}$ at $540^{\circ} \mathrm{C}$ ) was also performed in present work. The heating rate is $5^{\circ} \mathrm{C} / \mathrm{min}$ and all the samples after solution treatments were quenched in water at room temperature for the metallographic observation and microhardness test. On the other hand, the samples for tensile and creep tests were further aged at a $200{ }^{\circ} \mathrm{C}$ for 5 hours to fulfil the industrial T7 temper. The tensile samples were machined following the ASTM E8 standard. The samples had a gauge length of $60 \mathrm{~mm}$ and a diameter of $13 \mathrm{~mm}$. Tensile tests were performed by an Instron 8801 servo-hydraulic testing system at strain rate of $5 \times 10^{-2} \mathrm{~s}^{-1}$. Both $356 \mathrm{NM}$ and $356 \mathrm{M}$ alloys were tested at room temperature and elevated temperature $\left(300^{\circ} \mathrm{C}\right)$ and the tensile properties were obtained from the average value of three test samples. For the tensile temperature at $300{ }^{\circ} \mathrm{C}$, the heating process is controlled by three-zone furnace equipped on the tensile-test machine and time to reach $300{ }^{\circ} \mathrm{C}$ is 20 mins and then the sample was held at $300^{\circ} \mathrm{C}$ for 5 mins to stabilize. In addition, creep samples with cylindrical gauge length of $15 \mathrm{~mm}$ and diameter of $10 \mathrm{~mm}$ were machined. Compression creep tests were conducted at $300{ }^{\circ} \mathrm{C}$ for $100 \mathrm{~h}$ under a constant load of $43.5 \mathrm{MPa}$.

After casting and solution treatments, specimens were polished for metallographic examination. $0.5 \%$ HF etching solution was used to reveal the distribution of dispersoids. An optical microscopy (Nikon Eclipse ME600) and a scanning electron microscopy (SEM, JEOL JSM-6480LV) equipped with energydispersive X-ray spectroscopy (EDS) were used to investigate intermetallic phases and dispersoids. Vickers microhardness tests were performed on polished samples before etching (at least 15 tests for each sample) using a hardness tester (NG1000-CCD) with dwell time of $15 \mathrm{~s}$ and $25 \mathrm{~g}$ force at room temperature. During the hardness tests, the indentations are guaranteed inside the dendrites without touching the 
intermetallics formed during the solidification in order to show the evolution of hardness from the aluminum matrix. The characters of dispersoids, including the average size and number density, were measured from SEM images at 1000x. At least five views were characterized, which contained more than few hundreds of dispersoids ensuring that the statistical calculation is reliable and repeatable. A transmission electron microscope (TEM, JEOL JEM-2100) equipped with an EDS was operated at 200 $\mathrm{kV}$ to confirm the morphology and chemical composition of dispersoids.

\section{Acknowledgements}

The authors acknowledge the financial support of the Natural Sciences and Engineering Research Council of Canada (NSERC) and Rio Tinto Aluminum through the NSERC Industry Research Chair in the Metallurgy of Aluminum Transformation at the University of Quebec at Chicoutimi. 


\section{References}

1. G. Liu, and D. B. Müller: Addressing sustainability in the aluminum industry: a critical review of life cycle assessments. J. Clean. Prod., 35, 108-117(2012).

2. T. Norgate, S. Jahanshahi, and W. Rankin: Assessing the environmental impact of metal production processes. J. Clean. Prod., 15(8-9), 838-848(2007).

3. T. Team: Trends in Steel Usage in the Automotive Industry. Forbes. (2015, 20 March).

4. G. Cole, and A. Sherman: Light weight materials for automotive applications. Mater. Charact., 35(1), 3-9(1995).

5. H. Ye: An overview of the development of Al-Si-alloy based material for engine applications. $J$. Mater. Eng. Perform., 12(3), 288-297(2003).

6. M. Garat, and G. Laslaz: Improved aluminum alloys for common rail diesel cylinder heads. AFS Transactions, 115, 89-96(2007).

7. F. Feikus: Optimization of Al-Si cast alloys for cylinder head applications. AFS Transactions, 106, 225-231(1998).

8. M. Murayama, and K. Hono: Pre-precipitate clusters and precipitation processes in $\mathrm{Al}-\mathrm{Mg}-\mathrm{Si}$ alloys. Acta Mater, 47(5), 1537-1548(1999).

9. Y. Li, S. Brusethaug, and A. Olsen: Influence of $\mathrm{Cu}$ on the mechanical properties and precipitation behavior of AlSi7Mg0. 5 alloy during aging treatment. Scripta Mater., 54(1), 99103(2006). 
10. G. Sha, H. Möller, W. E. Stumpf, J. Xia, G. Govender, and S. Ringer: Solute nanostructures and their strengthening effects in Al-7Si-0.6 Mg alloy F357. Acta Mater., 60(2), 692-701(2012).

11. K. Matsuda, S. Taniguchi, K. Kido, Y. Uetani, and S. Ikeno: Effects of Cu and transition metals on the precipitation behaviors of metastable phases at $523 \mathrm{~K}$ in Al-Mg-Si alloys. Mater. Trans., 43(11), 2789-2795(2002).

12. S. Wang, K. Matsuda, T. Kawabata, T. Yamazaki, and S. Ikeno: Variation of age-hardening behavior of TM-addition Al-Mg-Si alloys. J. Alloys Compd., 509(41), 9876-9883(2011).

13. K. Liu, and X.-G. Chen: Development of Al-Mn-Mg 3004 alloy for applications at elevated temperature via dispersoid strengthening. Mater. Des., 84, 340-350(2015).

14. K. Liu, and X.-G. Chen: Evolution of intermetallics, dispersoids, and elevated temperature properties at various Fe contents in Al-Mn-Mg 3004 alloys. Metall. Mater. Trans. B, 47(6), 3291$3300(2016)$.

15. A. M. F. Muggerud, E. A. Mørtsell, Y. Li, and R. Holmestad: Dispersoid strengthening in AA3xxx alloys with varying Mn and Si content during annealing at low temperatures. Mater. Sci. Eng., A, 567, 21-28(2013).

16. L. Ratke, and P. W. Voorhees: Growth and coarsening: Ostwald ripening in material processing, (Springer Science \& Business Media, 2013),

17. R. Chen, Q. Xu, Z. Jia, and B. Liu: Precipitation behavior and hardening effects of Si-containing dispersoids in Al-7Si-Mg alloy during solution treatment. Mater. Des., 90, 1059-1068(2016).

18. Y. Li, A. Muggerud, A. Olsen, and T. Furu: Precipitation of partially coherent $\alpha-\mathrm{Al}(\mathrm{Mn}, \mathrm{Fe}) \mathrm{Si}$ 
dispersoids and their strengthening effect in AA 3003 alloy. Acta Mater., 60(3), 10041014(2012).

19. L. Lodgaard, and N. Ryum: Precipitation of dispersoids containing $\mathrm{Mn}$ and/or $\mathrm{Cr}$ in $\mathrm{Al}-\mathrm{Mg}-\mathrm{Si}$ alloys. Mater. Sci. Eng., A, 283(1-2), 144-152(2000).

20. H. Y. Kim, T. Y. Park, S. W. Han, and H. M. Lee: Effects of Mn on the crystal structure of $\alpha-A 1$ (Mn, Fe) Si particles in A356 alloys. J. Cryst. Growth, 291(1), 207-211(2006).

21. Y. Li, and L. Arnberg: Quantitative study on the precipitation behavior of dispersoids in DC-cast AA3003 alloy during heating and homogenization. Acta Mater., 51(12), 3415-3428(2003).

22. S. W. Nam, and D. H. Lee: The effect of Mn on the mechanical behavior of Al alloys. Met. Mater. Int, 6(1), 13(2000).

23. D. S. Park, and S. W. Nam: Effects of manganese dispersoid on the mechanical properties in AlZn-Mg alloys. J. Mater. Sci, 30(5), 1313-1320(1995).

24. K. Kim, and S. W. Nam: Effects of Mn-dispersoids on the fatigue mechanism in an $\mathrm{Al}-\mathrm{Zn}-\mathrm{Mg}$ alloy. Mater. Sci. Eng., A, 244(2), 257-262(1998).

25. D. Lee, J. Park, and S. W. Nam: Enhancement of mechanical properties of Al-Mg-Si alloys by means of manganese dispersoids. MSTec, 15(4), 450-455(1999).

26. A. Farkoosh, X. G. Chen, and M. Pekguleryuz: Dispersoid strengthening of a high temperature Al-Si-Cu-Mg alloy via Mo addition. Mater. Sci. Eng., A, 620, 181-189(2015).

27. A. Farkoosh, X. G. Chen, and M. Pekguleryuz: Interaction between molybdenum and manganese to form effective dispersoids in an $\mathrm{Al}-\mathrm{Si}-\mathrm{Cu}-\mathrm{Mg}$ alloy and their influence on creep resistance. 
Mater. Sci. Eng., A, 627, 127-138(2015).

28. C. M. Dinnis, J. A. Taylor, and A. K. Dahle: As-cast morphology of iron-intermetallics in Al-Si foundry alloys. Scripta Mater., 53(8), 955-958(2005).

29. S. Seifeddine, S. Johansson, and I. L. Svensson: The influence of cooling rate and manganese content on the $\beta$-A15FeSi phase formation and mechanical properties of Al-Si-based alloys. Mater. Sci. Eng., A, 490(1-2), 385-390(2008).

30. A. Farkoosh, and M. Pekguleryuz: Enhanced mechanical properties of an Al-Si-Cu-Mg alloy at $300 \mathrm{C}$ : effects of Mg and the Q-precipitate phase. Mater. Sci. Eng., A, 621, 277-286(2015).

31. K. Liu, H. Ma, and X.-G. Chen: Enhanced elevated-temperature properties via Mo addition in Al-Mn-Mg 3004 alloy. J. Alloys Compd., 694, 354-365(2017).

32. Y. Li, and L. Arnberg: Evolution of eutectic intermetallic particles in DC-cast AA3003 alloy during heating and homogenization. Mater. Sci. Eng., A, 347(1-2), 130-135(2003).

33. K. E. Knipling, D. C. Dunand, and D. N. Seidman: Criteria for developing castable, creepresistant aluminum-based alloys-A review. Z. Metallkd, 97(3), 246-265(2006).

34. J. G. Kaufman: Properties of aluminum alloys: tensile, creep, and fatigue data at high and low temperatures, (ASM international, 1999),

35. W.-S. Lee, and Y.-C. Huang: Mechanical Properties and Dislocation Substructure of 6061-T6 Aluminum Alloy Impacted at Cryogenic Temperatures. Mater. Trans., 57(3), 344-350(2016).

36. H. Adachi, Y. Miyajima, M. Sato, and N. Tsuji: Evaluation of dislocation density for 1100 aluminum with different grain size during tensile deformation by using in-situ X-ray diffraction 
technique. Mater. Trans., 56(5), 671-678(2015).

37. O. Sitdikov, E. Avtokratova, T. Sakai, and K. Tsuzaki: Ultrafine-grain structure formation in an Al-Mg-Sc alloy during warm ECAP. Metall. Mater. Trans. A, 44(2), 1087-1100(2013).

38. W. Wang, Y. Ma, M. Yang, P. Jiang, F. Yuan, and X. Wu: Strain Rate Effect on Tensile Behavior for a High Specific Strength Steel: From Quasi-Static to Intermediate Strain Rates. Metals, 8(1), 11(2017).

39. D. Fang, Q. Duan, N. Zhao, J. Li, S. Wu, and Z. Zhang: Tensile properties and fracture mechanism of Al-Mg alloy subjected to equal channel angular pressing. Mater. Sci. Eng., A, 459(1-2), 137-144(2007).

40. M. Warmuzek: Aluminum-silicon casting alloys: an atlas of microfractographs, (ASM international, 2004),

41. L. Pan, K. Liu, F. Breton, and X. G. Chen: Effect of Fe on microstructure and properties of 8xxx aluminum conductor alloys. J. Mater. Eng. Perform., 25(12), 5201-5208(2016).

42. G. E. Dieter, and D. J. Bacon: Mechanical metallurgy, (McGraw-hill New York, 1986), 
Figure captions:

Fig. 1 As-cast microstructure of experimental alloys: (a-b) for 356NM and (c-d) for 356M

Fig. 2 OM images of experimental alloys after $8 \mathrm{~h}$ solution treatment at $540{ }^{\circ} \mathrm{C}$ : (a) $356 \mathrm{NM}$ and (b) $356 \mathrm{M}$ alloys

Fig. 3 The distribution (a) and morphology (b) of $\alpha$-dispersoids, and TEM-EDS result of $\alpha$-dispersoids (c) and matrix (d) in $356 \mathrm{M}$ alloy (color online)

Fig. 4 The precipitation of dispersoids in $356 \mathrm{M}$ alloy when solution-treated for $24 \mathrm{~h}$ at: (a) $500{ }^{\circ} \mathrm{C}$, (b) $520^{\circ} \mathrm{C}$ and (c) $540{ }^{\circ} \mathrm{C}$

Fig. 5 Evolution of microhardness in 356NM (a) and differences of microhardness $(\triangle \mathrm{HV})$ between $356 \mathrm{NM}$ and $356 \mathrm{M}(\mathrm{b})$ during solution treatment at various temperatures (color online)

Fig. 6 Evolution of number density and average size of dispersoids during solution heat treatment at: (a) $500{ }^{\circ} \mathrm{C}$, (b) $520{ }^{\circ} \mathrm{C}$, (c) $540{ }^{\circ} \mathrm{C}$ and (d) 2-step (color online)

Fig. 7 Dispersoid evolution during solution treatment at: (a) $520^{\circ} \mathrm{C} / 2 \mathrm{~h}$, (b) $520^{\circ} \mathrm{C} / 12 \mathrm{~h}$, (c) $520^{\circ} \mathrm{C} / 24 \mathrm{~h}$, (d) $500^{\circ} \mathrm{C} / 4 \mathrm{~h}+540^{\circ} \mathrm{C} / 2 \mathrm{~h}$, (e) $500^{\circ} \mathrm{C} / 4 \mathrm{~h}+540^{\circ} \mathrm{C} / 8 \mathrm{~h}$ and (f) $500^{\circ} \mathrm{C} / 4 \mathrm{~h}+540^{\circ} \mathrm{C} / 12 \mathrm{~h}$

Fig. 8 Typical stress-strain curves of experimental alloys at: (a) room temperature and (b) $300{ }^{\circ} \mathrm{C}$ (color online)

Fig. 9 Tensile fracture surfaces of experimental alloys: (a, b) for RT and (c, d) for $300{ }^{\circ} \mathrm{C}$; (a) and (c) is from $356 \mathrm{NM}$ alloy while (b) and (d) is from 356M alloy

Fig. 10 Typical compressive creep curves of experimental alloys at $300{ }^{\circ} \mathrm{C}$ with a constant load of 43.5 MPa with indicated quasi-steady stage (color online) 